\title{
THE PRESENCE OF A VARIANT OF TYPE-IIIa $\beta$-LACTAMASE IN A SERIES OF STRAINS ISOLATED IN A BURNS UNIT
}

\author{
M. H. RICHMOND \\ Department of Bacteriology, University of Bristol, University Walk, Bristol BS8 1TD
}

EXPERIMENTS already reported suggest that a single clone of $\mathbf{R}$ factors was responsible for two sequential outbreaks of carbenicillin-reistant Pseudomonas aeruginosa, separated by a gap of about 6 months, in the Medical Research Council's Industrial Injuries and Burns Unit at the Birmingham Accident Hospital, Birmingham, England in 1969 (Lowbury et al., 1969; Ingram, Richmond and Sykes, 1973). Moreover, a plasmid which seems to belong to the same clone was isolated from strains of Klebsiella aerogenes between the periods during which carbenicillin-resistant strains of $P$. aeruginosa were prevalent (Ingram et al., 1973).

One of the strains of $P$. aeruginosa isolated during the first period of occurrence of carbenicillin resistance carried the R-factor RP1 and this element has subsequently been studied extensively in various laboratories (Sykes and Richmond, 1970; Grinstead et al., 1972; Holloway and Richmond, 1973; Olsen and Shipley, 1973). Its marker pattern is ApNeTc (Ampicillin, Neomycin, Tetracycline) and the carbenicillin-resistant phenotype has been shown to be due to a $\beta$-lactamase that cross-reacts with an antiserum prepared against purified $\beta$-lactamase type IIIa (Sykes and Richmond, 1970; Richmond and Sykes, 1973), a penicillinase commonly specified by $\mathrm{R}$ factors (Datta and Richmond, 1966; Richmond and Sykes, 1973).

Subsequent experiments have shown that, although giving a " reaction of identity" with anti-type-IIIa serum in gel precipitation tests, the enzyme specified by the R-factor RPI is seen not to be identical with the classical type-IIIa enzyme when subjected to iso-electric focusing in polyacrylamide gels (Matthew et al., 1975). The present note shows that this variant of type-HIa $\beta$-lactamase is synthesised by representative $\mathbf{R}$ factors occurring in $P$. aeruginosa drawn from each of the two phases of carbenicillin resistance encountered in the Burns Unit (R factors RP1 and RP9) and also from a plasmid found in a strain of $K$. aerogenes ( $R$-factor RK3) isolated during the period between these two phases.

\section{Materials AND Methods}

$R$ plasmids and bacterial strains. The plasmids chosen for study-RP1, RP9 and RK3originated in $P$. aeruginosa strains nos. 1822 and 9169 and in $K$. aerogenes strain no. 7418 respectively (Lowbury et al., 1969; Ingram, Richmond and Sykes, 1973). The enzymes specified by R1822 and R9196 were studied in the original strains of $P$. aeruginosa in which they were originally isolated, whilst RK3 was examined after transfer to an R strain of Escherichia coli $\mathrm{K} 12$ (E. coli strain no. UB1005) (Ingram et al., 1973). Standard type-IIIa $\beta$-lactamase was prepared from $E$. coli strain no. W3110 carrying the plasmid $\mathrm{R}_{\mathrm{TEM}}$, alias R6K (Datta and Richmond, 1966; Richmond and Sykes, 1973).

Preparation of $\beta$-lactamases. Cultures $(50 \mathrm{ml})$ were grown in Oxoid Brain Heart Infusion broth for $18 \mathrm{~h}$ at $37^{\circ} \mathrm{C}$ and harvested by centrifugation at $5000 \mathrm{~g}$ for $15 \mathrm{~min}$. Intracellular $\beta$-lactamase was released by grinding aqueous suspensions of bacteria with sand in a mortar. Sand and the cell debris were then removed by centrifugation at $5000 \mathrm{~g}$ for $30 \mathrm{~min}$. The supernate containing the enzyme was concentrated by freeze-drying when necessary.

Iso-electric focusing. The $\beta$-lactamase preparations were compared by iso-electric focusing in thin layers of polyacrylamide gel as described by Matthew and her collaborators (Matthew et al., 1975). Immuno-iso-electric focusing was also carried out as described by those authors.

\section{Results AND Discussion}

The iso-electric focusing patterns of the $\beta$-lactamases produced by strains of $P$. aeruginosa no. 1822 (RP1), P. aeruginosa no. 9169 (RP9) and E. coli no. UB1005 (RK3) were compared with that of the enzyme from $E$. coli $\mathrm{K} 12\left(\mathrm{R}_{\mathrm{TEM}}\right)$. The patterns of the $\beta$-lactamases specified by RP1, RP9 and RK3 all had characteristic main bands at pI $=5.6$ (see Matthew et al., 
1975), and this pattern was quite distinct from that of the reference preparation of type-IIIa enzyme prepared from $E$. coli $\left(\mathrm{R}_{\mathrm{TEM}}\right)$ which had a main band at pI 5.4.

Antiserum prepared against purified type-IIIa enzyme (Datta and Richmond, 1966) showed a reaction of identity, both by neutralisation tests and by gel precipitation with the enzyme specified by $R_{\text {TEM }}$ (Sykes and Richmond, 1970).

The cross-reaction between the antiserum prepared against purified $R_{\text {TEM }}$ enzyme and the $\beta$-lactamases specified by RP1, RP9 and RK 3 was confirmed by immuno-iso-electric focusing.

To date, the particular variant of Type-IIIa enzyme with a pl value of 5.6 has been found only among P-class R plasmids, all of which-save only RK3-originated in strains of $P$. aeruginosa. The presence of a plasmid specifying this particular variant of type-IIIa $\beta$ lactamase in $K$. aerogenes carried in the alimentary tracts of people working in the Burns Unit between the two periods when carbenicillin resistant $\boldsymbol{P}$. aeruginosa strains were isolated, provides additional support for the view that the reservoir of carbenicillin resistance genes was maintained in klebsiella strains during the period in which carbenicillin therapy was stopped in the unit (Lowbury et al., 1969; Lowbury, Babb and Rowe, 1972).

\section{SUMMARY}

An outbreak of carbenicillin-resistant Pseudomonas aeruginosa infection in a Burns Unit in 1968-69 occurred in two phases separated by a period when no resistant pseudomonas were detected. Nevertheless, strains of Klebsiella aerogenes carrying R factors similar to those in the pseudomonas strains were encountered in the intervening period. The similarity of the plasmids occurring in all stages of this outbreak has been confirmed by the fact that each specifies a novel variant of type-IIIa $\beta$-lactamase.

I am very grateful to Drs Gordon Ross and Margaret Matthew for carrying out the immuno-iso-electric focusing and some of the normal iso-electric focusing experiments. I am grateful to Beecham Research Laboratories for a generous gift of carbenicillin. This work was supported by a grant from the Medical Research Council.

\section{REFERENCES}

DatTA, N. AND RICHMOND, M. H. 1966. The purification and properties of a penicillinase whose synthesis is mediated by an R-factor in Escherichia coli. Biochem. J., 98, 204.

Grinsted, J., Saunders, J. R., Ingram, J. C., Sykes, R. B. ANd Richmond, M. H. 1972. Properties of an R-factor which originated in Pseudomonas aeruginosa 1822. J. Bact., $110,529$.

Holloway, B. W. AND RICHMOND, M. H. 1973. R-factors used for genetic studies in strains of Pseudomonas aeruginosa and their origin. Genet. Res., 21, 103.

INGRAM, L. C., RICHMOND, M. H. AND SyKes, R. B. 1973. Molecular characterization of the $\mathrm{R}$-factors implicated in the carbenicillin resistance of a sequence of Pseudomonas aeruginosa strains isolated from burns. Antimicrob. Agents Chemother., 3, 279.

LOWBURY, E. J. L., BABB, J. R. AND RowE, E. 1972. Clearance from a hospital of Gram-negative bacilli that transfer carbenicillin resistance to Pseudomonas aeruginosa. Lancet, 2,941 .

Lowbury, E. J. L., Kidson, A., Lilly, N. A., Ayliffe, G. A. J. AND Jones, R. J. 1969. Sensitivity of Pseudomonas aeruginosa to antibiotics: emergence of strains highly resistant to carbenicillins. Lancet, 2, 448.

Matthew, M., Harris, A. M., Marshall, M. J. and Ross, G. W. 1975. The use of analytical isoelectric focusing for detection and identification of $\beta$-lactamases. J. gen. Microbiol., 88, 169.

Olsen, R. H. AND ShIPley, P. 1973. Host range and properties of the Pseudomonas aeruginosa R-factor R1822. J. Bact., 113, 772.

Richmond, M. H. AND SyKes, R. B. 1973. The $\beta$-lactamases of Gram-negative bacteria and their possible physiological role. In Advances in microbial physiology, vol. 9, edited by A. H. Rose and D. W. Tempest, New York and London, p. 31.

SYKes, R. B. AND RICHMOND, M. H. 1970. Intergeneric transfer of a $\beta$-lactamase gene between Pseudomonas aeruginosa and Escherichia coli. Nature, Lond., 226, 952. 